\title{
Myelodysplastic syndromes (MDS): prognostic factors and scoring systems
}

Department of Hematology, Department of Biostatistics and Department of Pathology, Department of Hematology, Faculdade de Medicina de Botucatu, Escola Paulista de Medicina/ UNIFESP - São Paulo, Brazil

Objective: To evaluate the score systems of Cassano and Sanz and suggest a new one. Design: Case series. Location: Teaching hospitals: EPM UNIFESP and Faculdade de Medicina de Botucatu. Participants: 59 patients diagnosed from 1979 to 1992 . Intervention: Evaluation of clinical-laboratorial data. Measurement: Statistical comparison, uni and multivariate analysis and actuarial survival curves. Results: Cassano's system divided the patients into high and low risk $(p=0.0966)$ while Sanz's gave high, intermediate and low risk $(\mathrm{p}=0.0108)$. The univariate analysis showed hemoglobin, WBC count, $E / M$ ratio, liver size and blast percentage in $B M$ as statistically significant. The multivariate analysis showed blast percentage in $B M(p=0.004)$ and $\mathrm{Hb}(p=0.050)$ as significant. Our system, considering the multivariate analysis data, divided the patients into high, intermediate and low risk ( $p=0.0038$ ). Conclusions: Sanz's system was more functional than Cassano's, while ours showed predictive survival value and ease of use in clinical practice.

UNITERMS: Myelodysplastic syndromes. Prognosis. Survival.

\section{INTRODUCTION}

$\mathrm{M}$ yelodysplastic syndromes (MDS) are a complex group of hematological disorders characterized by hypercellular bone marrow with dyshematopoiesis involving one or more cell lineages and peripheral blood cytopenias that frequently transform into acute leukemia ${ }^{1,2,3}$.

Different authors have stressed that the MDS classification, proposed by the French-American-British (FAB) cooperative group in $1982^{3}$ is only able to separate patients into two risk groups: refractory anemia (RA) plus refractory

\section{Adress for correspondence:}

Maria de Lourdes L. F. Chauffaille

Rua Botucatu $740,3^{\circ}$ andar

São Paulo/SP - Brasil - CEP 04023-062 anemia with ringed sideroblasts (RARS) (low risk) and refractory anemia with excess of blasts (RAEB) plus refractory anemia with excess of blasts in transformation (RAEB-t) (high risk) ${ }^{4}, 5,6,7.89,10,11$. The chronic myelomonocytic leukemia (CMMoL) group lacks a clearlydefined risk classification $6,7,9,10,12,13$.

During the last 10 years there has been a growing interest in the analysis of variables of prognostic value in MDS, especially bacause of cases with unexpected clinical evolution or unclassified according to FAB criteria ${ }^{14}$. Prognostic studies have recently been proposed using variables selected by univariate and multivariate regression analysis. Therefore, many scoring systems for predicting survival and leukemic transformation, as well as for selecting adequate therapeutic approaches for each individual case, have been proposed $9,11,15,16,17,18$.

The aims of this study were: 1) To evaluate the established scoring systems published by Cassano ${ }^{15}$ and 
Sanz ${ }^{17}$ in our group of patients, 2) To access variables of prognostic value and 3) To propose a new, simplified scoring system easy to use in clinical practice.

\section{MATERIALS AND METHODS:}

We studied 59 patients with MDS that were diagnosed at two different teaching hospitals in the state of São Paulo (Escola Paulista de Medicina/UNIFESP and Hospital da Faculdade de Medicina de Botucatu - Hospital da UNESP) from 1979 to 1992.

All patients were classified according to the estabilished scoring systems of Cassano ${ }^{15}$ (Table 1) and Sanz $z^{17}$ (Table 2).

Only patients with primary MDS were analyzed, and therefore those with poor prognosis (secondary and/or therapy-related MDS) were excluded. Patients who had more than $30 \%$ of blast cells in bone marrow were also excluded ${ }^{2}$.

Clinical, laboratorial and bone marrow cytohistological data were collected from all patients according to FAB criteria ${ }^{3}$.

Peripheral blood and bone marrow smears were dyed with Leishman's stain. Hemoglobin level (g/dl), reticulocytes $(\%)$, WBC $\left(\times 10^{9} / 1\right)$, neutrophils $(\%)$, monocytes $(\%)$, lymphocytes $(\%)$, blast cells $(\%)$ and platelet count $\left(\mathrm{x} 10^{9} / \mathrm{l}\right)$ were determined.

Bone marrow aspiration and biopsy materials were dyed with hematoxilin-eosin (HE) and Giemsa stains and stained for reticulin by the Gomori method and were examined for: 1) cellularity $(\mathrm{BM} /$ fat ratio $<1 / 3=$ hypocellular $=$ grade $0 ; \mathrm{BM}$ fat ratio $1 / 3-1 / 1=$ normocellular $=$ grade $1 ; \mathrm{BM} /$ fat ratio $>1 / 1=$ grade $2 ; 2$ ) erythro/myeloid ratio ( $>0.53$ or $<0.53) ; 3$ ) BM blast cell percentage; 4) dyserythropoiesis (proerythroblast excess, erythoblasts arrested at the same stage, scattered erythroblasts); 5) dysgranulopoiesis (dysplastic changes, Pelger Huet abnormality, degranulation of mature neutrophils); 6) dysmegakaryocytopoiesis (dystrophy, abnormal size and nuclear lobulations): grade $0-2+=0-$ $30 \%$ abnormal cells, grade $3+-4+=31-60 \%$ abnormal cells, grade $5+-6+=61-100 \%$ abnormal cells; 7) BM fibrosis $(0-1+=$ absent, $2+=$ moderate, $3+=$ significant $)$; 8) ALIP - abnormal localization of immature precursors, according to the criteria of Tricot et al. Criteria: grade $0+$ $=<3$ clusters, $1+=3-4$ clusters, $2+=>4$ clusters; 9) $\mathrm{BM}$ sideroblasts $(<15 \%$ or $>15 \%)$. Differential counts were performed on at least 500 marrow cells. All cases were reviewed by two hematologists independently (EXS and
MLLFC) and were allocated to the appropriate FAB subgroup.

Clinical features such as sex, race, age, interval between first symptoms and diagnosis, liver and spleen enlargement, and survival time were also examined.

In addition, cases were classified according to a scoring system using the significant variables of univariate and multivariate analysis.

\section{Statistical Analysis}

Actuarial survival probability curves were plotted according to the method of Kaplan and Meyer ${ }^{19}$. Different curves were compared statistically using the Cox-Mantel (log rank) or the generalized Wilcoxon test ${ }^{20}$. For univariate analysis, the cut-off level of each quantitative variable was established based on data in the literature. In some cases, the cut-off was established by trial and error, until "p" values were found close to $5 \%$. For qualitative variables, the different categories were compared to each other. After prognostic features were selected by univariate analysis, multivariate analysis was performed according to Cox's model $^{21}$. Variables which remained significant were included in the equation, the relative risk for each patient was estimated, and the population was divided into three risk groups: low, intermediate and high.

\section{RESULTS}

The 59 patients were followed up from 0.4 to 103 months. There were 31 men $(52.6 \%)$ and $28(47.4 \%)$ women. 51 of the patients $(86.5 \%)$ were white and 8 $(13.5 \%)$ were black. The median age was 56 years (range $16-86)$, and $33(55.9 \%)$ were younger and $26(44 \%)$ were older than 60 years of age, with a median survival of 35.30 and 46.20 months, respectively $(\mathrm{p}=0.5013)$. The general median survival was 35.50 months.

Univariate analysis indicated six variables associated with poor prognosis $(\mathrm{p}<0.05)$ : liver enlargement $(\mathrm{p}=0.0070), \mathrm{WBC} 2.0 \times 10^{9} / 1(\mathrm{p}=0.0214)$, BM blast cell percentage when comparing the groups: $<5 \%, 5 \%-10 \%$ and $>10 \%(\mathrm{p}=0.0025)$, erythroid/myeloid $(\mathrm{E} / \mathrm{M})$ ratio 0.40 $(\mathrm{p}=0.0456), \mathrm{FAB}$ classification (RAEB plus RAEB-t, $\mathrm{p}=0.3670)$, and hemoglobin level $6 \mathrm{~g} / \mathrm{dl}(\mathrm{p}=0.0526)$ (Table. 1). Twenty patients had RA $(33.9 \%), 12(20.3 \%)$ RARS, $16(27.1 \%)$ RAEB, 2 (3.4\%) RAEB-t, 5 (8.5\%) LMMoC and $4(6.8 \%)$ were unclassified. The median survivals were: $88.7,57.4,24.2,3.4,31.1$ and 17.0 months respectively. 
Isolated comparison among all groups was not significant ( $\mathrm{p}=0.1404$ ), but in grouping between RA plus RARS versus RAEB plus RAEB-t, statistical significance was found $(p=0.0367)$ ), with median survivals of 84.7 months versus 19.3 , respectively. The variables of sex, race, age, interval between first symptoms and diagnosis, spleen enlargement, platelet counts, BM cellularity, erythroid/myeloid ratio $(<0.53$ or $>0.53)$, dyserythropoiesis, dysmyelopoiesis, dysmegakaryocytopoiesis, BM fibrosis and presence of ALIPs were not significant at the different cut-off levels examined.

Multivariate analysis showe 2 variables of prognostic importance: BM blast cell percentage $(p=0.0040)$ and hemoglobin levels $(p=0.0050)$. The equation derived from multivariate analysis was: $\mathrm{RR}=\operatorname{Exp} \mathrm{I}(0.09163 \times \mathrm{BM}$ blast cells $)-(0.2336 \times \mathrm{Hb}) \mathrm{l}$, where $\mathrm{RR}=$ relative risk.

The patients were then divided into 3 risk groups: low (RR $0.04-0.15$ ), intermediate (RR $0.18-0.33$ ) and high (RR 0.36 - 2.57). The Wilcoxon test showed a siginificant difference in survival when low versus high $(\mathrm{p}=0.0346)$ and low versus intermediate risk groups (Figure 1) were compared.

Applying Cassano's scoring system to our population there were 11 patients $(26.8 \%)$ with score 5 and survival above $50 \%$ in the period of study period and 30 patients (73.1\%) with score 5 and median survival of 31.10 months $(\mathrm{p}=0.0966)$ (Figure 1). Applying Sanz's scoring system there were 27 patients $(49.10 \%)$ with score $0-1$ and a median survival of 84.7 months; 23 patients $(41.18 \%$ ) with score 2-3 and a median survival of 16.1 months; 5 patients $(9.10 \%)$ with score $4-5$ and median survival of 7.2 months. Significant statistical difference was seen among the survival curves $(\mathrm{p}=0.0108$ ) (Figure 2 ).

Considering the significant variables of univariate and multivariate analysis a new scoring system was elaborated:

\begin{tabular}{lccc}
\hline & 0 & 1 & 2 \\
\hline BM blast cells $(\%)$ & $<5$ & $5-10$ & $>10$ \\
$\mathrm{Hb}(\mathrm{g} / \mathrm{dl})$ & $>6$ & $\geq 6$ & \\
$\mathrm{WBC}\left(\mathrm{x} 10^{9} / \mathrm{l}\right)$ & $>2.0$ & $\geq 2.0$ & \\
E/M ratio & $>0.40$ & $\geq 0.40$ & \\
\hline
\end{tabular}

This scoring system divides the patients into three risk groups: group 0 (low risk) - 19 patients $(32.2 \%)$ with survival above $80 \%$ in the study period; group 1 (intermediate risk) - 21 patients $(35.5 \%)$ with median survival of 31.10 months and group $2+3$ (high risk) -19 patients $(32.2 \%)$, with median survival of 12.80 months. When comparing the survival curves of low versus intermediate $(\mathrm{p}=0.00056)$ and low versus high groups $(\mathrm{p}=$ 0.0006 ), there was a significant difference, but not when intermediate versus high risk groups were compered $(\mathrm{p}=0.0869)$ (Figure 5)

\section{DISCUSSION}

The general median survival in the present group of patients was 35.50 months, longer than seen in most studies. The median age was 56 years, a number lower than seen in published papers ${ }^{9} 10.17$.

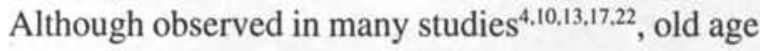
is not significant in the Brazilian population (mean age of 21,7 years). On dividing the patients into two groups, above and below 60 years old, as $S a n z^{17}$ proposed, we observed median survivals of 46.2 and 35.3 months ( $\mathrm{p}=0.5013$ ).

Using univariate analysis, liver size was a significant variable. Patients with an enlarged liver had a survival of 19.30 months versus 84.70 months in those with unpalpable liver $(\mathrm{p}=0.0070)$. This was probably associated with more aggressive $\mathrm{FAB}$ groups and with the liver infiltration seen in more "aggressive" FAB subgroups (RAEB, RAEB-t and CMMoL).

Hemoglobin values were analyzed in the same manner as in Sanz's ${ }^{17}$ work, comparing the survival curves of three groups: as proposed by Sanz et al. (1989): $<8 \mathrm{~g} \%, 8-10$ $\mathrm{g} \%$ and $>10 \mathrm{~g} \%$, but was not significant. When the patients were divided into two groups, with $\mathrm{Hb} 6 \mathrm{~g} / \mathrm{dl}$ (median survival of 24.40 months) and with $\mathrm{Hb}>6 \mathrm{~g} / \mathrm{dl}$ (median survival of 49.60 months), univariate and multivariate analysis showed statistically significant difference. These results confirm that hemoglobin levels are an important prognostic indicator, agreeing with other authors $^{4,9,13,17,22,23,24,25,26}$.

Univariate analysis showed that WBC count was significant ( $\mathrm{p}=0.0214$ ) when the survival curves of groups with WBC counts of $2.0 \times 10^{\circ} / 1$ (median survival of 16.10 months) and $>2.0 \times 10^{9} / 1$ (median survival of 46.20 months) were compared $(\mathrm{p}=0.0214)$, confirming the importance of peripheral cytopenias as observed by others ${ }^{17}$.

In contrast to the literature, in this study platelet counts did not appear to be a significant prognostic factor in this population. Sanz et al. (1989) observed significant difference among survival curves of groups with $50 \times 10 \%$ 1, $50-100 \times 10^{9} / 1$ and $100 \times 10^{9} / 1$ platelet counts, and Varela et $\mathrm{al}^{11}$ showed that groups with $<20 \times 10^{9} / 1$ platelet counts had a poor prognosis.

Bone marrow cellularity was not significant, but the median survival in the group with normocellularity was higher ( 84.70 months) than that of the hypercellular and 
hypocellular groups (35.50 and 31.10 months respectively). Some authors have stressed that BM hypercellularity is an indicator of poor prognosis ${ }^{11,22,27}$. BM qualitative variables such as dyserythropoiesis, dysgranulopoiesis and dysmetakaryiocytopoiesis were not statistically significant.

BM fibrosis was present to some extent in $40 \%$ of patients, but was not significant.

The presence of ALIPs in BM biopsies has been demonstrated ${ }^{10,25,28,29,30,31}$ as a significant prognostic factor, but not in the present population.

Comparisons of erythro/myeloid ratio were significant $(\mathrm{p}=0.0456)$ in univariate analysis when comparing the survival curves of groups with $R E / M<0.40$ versus $>0.40$, with median survival of 19.60 and 84.70 months respectively $(\mathrm{p}=0.0456)$. This was also observed by Cassano ${ }^{15}$, when comparing the survival curves of groups with $R E / M<0.53$ versus $>0.53$. The significance of this variable may be related to the increase in myeloid lineage and BM blast cells.

The BM blast cells percentage was the most significant prognostic factor in seen in this population, as already stressed by many other authors $4,9,10,13,23,24,26$. Statistical significance was seen in univariate and multivariate analysis ( $\mathrm{p}=0.0025$ and $\mathrm{p}=0.0040$, respectively), when the following survival curves were compared:

- $<5 \%$ BM blast cells: median survival of 84.70 monthsnths.

- $5-10 \%$ BM blast cells: median survival of 35.30 months.

- $>10 \%$ BM blast cells: median survival of 7.20 months.

$\mathrm{BM}$ blast cell percentage, combined with the cytogenetics abnormalities, are considered to be the most important prognostic factors for survival of MDS patients.

Scoring system "A" of Cassano et al (1990) divided the patients into two risk groups: score $<5$ (low risk) with survival $>50 \%$ in the period analyzed, and score $>5$ (high risk ) with survival of 31.10 months, but was not statistically significant despite the difference in survival time. This is very interesting scoring because it included BM biopsy and qualitative data (dysmegakaryopoiesis, fibrosis and presence of ALIPs). This population showed a long survival rate in the high risk group (31.10 months), in concordance with the original work.

Using Sanz's scoring system (Sanz et al, 1989), patients were divided into three risk groups: score 0-1, with median survival of 84.70 months; score 2-3, with median survival of 16.10 months; score 4-5 months, with median survival of 7.20 months. The comparison of all survival curves was significant using the Wilcoxon test ( $\mathrm{p}=0.0108)$ and also using Cox Mantel: $0-1$ versus 2-3 $(\mathrm{p}=0.0027), 0-1$ versus $4-5(\mathrm{p}=0.0027)$ and $2-3$ versus $4-5$ $(p=0.0080)$. Sanz's system seems to be more appropriate and more easily applicable for clinical practice than Cassano's.

The population could be separated into three risk groups using Cox's relative risk model: $0.004-0.15$ - low risk, with $>50 \%$ survival during the period studied; 0.18 0.33 - intermediate risk, with $>50 \%$ survival during the period studied; and 0.36-2.57 - high risk, with survival of 16.10 months. The difference among the survival curves was significant $(\mathrm{p}=0.0165)$.

Using our proposed scoring system, which includes variables derived from univariate analysis, ie WBC count and $\mathrm{RE} / \mathrm{M}$, patients were divided into three risk groups: 0 (low) with survival above $80 \%$ during the study period; 1 (intermediate) with median survival of 31.10 months and $2+3$ (high) with median survival of 12.80 months $(\mathrm{p}=0.0038)$.

We conclude that the new scoring system presented here is easier to apply than Sanz's and Cassano's because it includes variables that are easily accessible to clinicians.

Cytogenetics abnormalities have been considered an important prognostic factor for survival of MDS patients. However, as it is not yet a test available to all patients, we consider that future studies in our country should include cytogenetic analysis.

\section{RESUMO}

Objetivo: Avaliar utilidades dos sistemas de escore de Cassano e Sanz e propor outro. Desenho: Serie de Casos. Local: Hospitais universitários: EPM-UNIFESP e Faculdade de Medicina de Botucatu. Participantes: 59 pacientes diagnosticados entre 1979 e 1992. Intervenção: Avaliação de parâmetros clínico-laboratoriais. Mensuração: Comparação estatística, análise uni e multivariada e curva de sobrevida atuarial. Resultados: O sistema de Cassano dividiu os pacientes em alto e baixo risco $(p=0.0966)$ enquanto $o$ de Sanz em alto, intermediário e baixo risco $(p=0.0108)$. A análise univariada demonstrou que hemoglobina, contagem de GB, relação EM, aumento do fígado e \% de blastos na medula (MO) eram estatisticarrente significantes. A regressão multivariada demonstrou como sendo significantes a \% de blastos da MO ( $p=0.004)$ e os níveis de $\mathrm{Hb}(\mathrm{p}=0.050)$. O nosso sistema, considerando os parâmetros da análise univariada, dividiu os pacientes em alto, intermediário e baixo risco $(p=0.0038)$. Conclusōes: O sistema de Sanz foi mais prático que o de Cassano enquanto o nosso, demonstrou valor preditivo de sobrevida e uso fácil na prática clínica. 


\section{REFERENCES}

1. Aksoy M, Erden S. Following study on the mortality and development of leukemia in 44 pancytopenic patients, with chronic exposure to benzene. Blood 1978; 52:285-292.

2. Bennet JM, Catovsky D, Daniel MT, Flandrin G, Galton DAG, Gralnick HR, Sultan C. Proposals for the classification of acute myeloid leukemia. Br J Haematol 1976; 3:451-458.

3. Bennet JM, Catovsky D, Daniel MT, Flandrin G, Galton DAG, Gralnick HR, Sultan C. Proposal for the classification of the myelodysplastic syndromes. Br J Haematol 1982; 51:189-199.

4. Coiffier B, Adeleine P, Gentilhomme O, Felman P, TreilleRitquet D, Bryon P. Myelodysplastic syndromes: A multiparametric study of prognostic factors in 336 patients. Cancer 1987; 60: 3029-3032.

5. Fenaux P, Estienne MH, Lepelley P, Zandecki M, Lai JL, Beuscart R, Jouet JP, Cosson A, Beuters F. Refractory anaemia according to the FAB classification: a report of 69 cases. Eur J Haematol 1988; 40:318-325.

6. Foucar K, Langdon RM, Olson DB, Carroll TJ. Myelodysplastic Syndromes: a clinical and pathologic analysis of 109 cases. Cancer 1985; 56: 553-561.

7. Garcia S, Sanz MA, Amigo V, Colomina P, Carrera MD, Lourenzo JI, Sanz GF. Prognostic factors in chronic myelodysplastic syndromes: a multivariate analysis in 107 cases. Am J Hemato 1988; 27:163-168.

8. Jacobs A. Myelodysplastic syndromes: pathogenesis, functional abnormalites and clinical implications. J Clin Pathol 1985; 38:1201-1217.

9. Mufti GJ, Stevens JR, Oscier DG, Hamblin TJ, Machin D. myelodysplastic syndromes: a scoring system with prognostic significance. Br J Haematol 1985; 59:425-433.

10. Tricot G, Vlietnick R, Boogaerts MA, Hendrickx B, De WolfPeeters C, Van Den Berghe H, Verwilghes RL. Prognostic factors in the myelodysplastic syndromes: importance of initial data on peripheral blood counts, bone marrow cytology, tephrine biopsy and chromosomal analysis. $\mathrm{Br} \mathrm{J}$ Haematol 1985; 60:19-32.

11. Varela BL, Chuang C, Woll JE, Bennett JM. Modifications in the classification of primary myelodysplastic syndromes: the addition of a scoring system. Hematol Oncol 1985; 3:5563.

12. Fenaux P, Beuscart R, Lai JL, Jouet JP, Bauters F. Prognostic factors in adult chronic myelomonocytic leukemia: an anlysis of 107 cases. J Clin Oncol 1988; 6:1417-1424.

13. Kerkhofs H, Hermans J, Haak HL, Leeksma CHW. Utility of the FAB classification for myelodysplastic syndromes: investigation of prognostic factors in 237 cases. $\mathrm{Br} \mathrm{J}$ Haematol 1987; 65:73-81.

14. Hoelzer D, Ganser A, Heimpl H. Atypical leukemias: preleukemia, smouldering leukemia and hypoplastic leukemia. Cancer Res 1984; 93:69-101.

15. Cassano E, Giordano M, Riccardi A, Coci A, Cazzola M. Myelodysplastic syndromes: multiparametric sutdy of prognostic factors and a proposed scoring system. Haematologica 1990; 75: 141-145.
16. Rubio-Félix D, Giraldo MP, Perella M, Gimeno J, Franco E, Giralt M. Análisis de cuatro sistemas de puntuoación ea 197 síndromes mielodisplásicos. Sangre 1991; 36(supll.1):463-469.

17. Sanz GF, Sanz MA, Vallespi T, Cañizo MC, Torrabadella M, García S, Irreguible D, Sanz Miguel JF. Two regression models and a scoring system for predicting survival and planning treatment in myelodysplastic syndromes: A multivariate analysis of prognostic factors in 370 patients. Blood 1989; 74(suppl.1): 395-408.

18. Worsley A, Oscier DG, Stevens J, Darlow S, Figes A, Mufti G, Hamblin TJ. Prognostic features of chronic myelomonocytic leukaemia: a modified Bournemouth score gives the best prediction of survival. Br J Haematol 1988; 68:17-21.

19. Kaplan EL; Meier P. Nonparametric stimulation from incomplete observations. J Am Stat Assoc. 1958; 53:457481.

20. Lee BS. Statistical methods for survival data analysis. Belmont Publication Lifetime Learning. 1980,pp 551p.

21. Cox DR. Regression models and life tables. J R Stat Soc (B). 1972; 34:187-202.

22. Riccardi A, Giordano M, Giordano P, Cassano E, Girino M, Cazzola M, Scivetti P, Danova M, Ucci G. Prognostic parameters in myelodysplastic syndromes: a multiple regression analysis. Eur J Haematol 1988; 40:158-162.

23. Coiffer B, Adeleine P, Viala JJ, Bryon PA, Fière D, Gentilhomme O, Vuvan H. Dysmyelopoietic syndromes: A multiparametric study of prognostic factors in 336 patients. Cancer 1987; 60: 3029-3032.

24. Goasguen JE, Garand R, Bizet M, Bremond JL, Gardais J, Callat MP, Accard F, Chaperon J. Prognostic factors of myelodysplastic syndromes: a simplified 3-D scoring system. Leukemia Res 1990; 14:255-262.

25. Tricot G, Vlietnick R, Verwilghen RL. Prognostic factors in myelodysplastic syndromes: a review. Scand J Haematol 1986; 36(suppl 45):107-113.

26. Van Der Weide M, Sizoo W, Nauta JJP, Krefft J, Langenhuijsen MMAC. Myelodysplastic syndromes: analysis of clinical and prognostic features in 96 patients. Eur J Haematol 1988;41:115-122.

27. Ríos A, Cañizo MC, Sanz MA, Vallespi T, Sanz G, Torrabadella M, Gomis F, Ruiz C, San Miguel JF. bone marrow biopsy in myelodysplastic syndromes: morphological characteristics and contribuition to the study of prognostic factors. Br J Haematol 1990; 75:26-33.

28. Melo LN, Franco M, Gushiken T, Guilherme EL, Machado PEA. Síndromes mielodisplásicas: avaliação clínica, hematológica e histopatológica da medula óssea em 23 casos. Rev Ass Med Brasil 1987;33(3/4):53-56.

29. Tricot G, De Wolf-Peeters C, Hendrickx B, Verwilghen RL. Bone marrow histology in myelodysplastic syndromes: histological findings in myelodysplastic syndromes and comparison with bone marrow smears. Br J Haematol 1984; 57:423-430.

30. Tricot G, De Wolf-Peeters C, Vlietnick R, Verwilghen RL. Bone marrow histology in myelodysplastic syndromes: prognostic value of abnormal localization of immature precursors in MDS. Br J Haematol 1984; 58:217-225. 